\title{
Model for Evaluation of the Concentration of Dissolved Phosphorus during Leaching of Iron Oxide Ore in Oxalic Acid Solution
}

\author{
C. I. Nwoye \\ Department of Materials and Metallurgical Engineering, \\ Federal University of Technology, Owerri, Imo State, Nigeria \\ E-mail: chikeyn@yahoo.com
}

\begin{abstract}
Model for evaluation of the concentration of dissolved phosphorus (relative to the final $\mathrm{pH}$ of the leaching solution) during leaching of iron oxide ore in oxalic acid solution has been derived. It was observed that the validity of the model is rooted in the relationship $\ln P=N / \alpha$ where both sides of the expression are approximately equal to 4. The model depends on the value of the final $\mathrm{pH}$ of the leaching solution which varies with leaching time. In all, the positive or negative deviation of the model-predicted phosphorus concentration from its corresponding value obtained from the experiment was found to be less than 22\%, which is quite within the acceptable deviation limit of experimental results hence establishing the validity and precision of the model.
\end{abstract}

Keywords: Model, Evaluation, Phosphorus dissolution, Oxalic Acid, Iron Oxide Ore, Leaching.

\section{INTRODUCTION}

The presence of $\mathrm{Fe}^{2+}$ was found to significantly enhance the leaching of iron extraction from silica sand at a temperature even as low as $25^{\circ} \mathrm{C}[1,2]$. Ferrous oxalate, however, is oxidized quickly by air during the dissolution and in general an induction period of a few hours was observed unless a strong acidic environment $(<\mathrm{pH} 1)$ or an inert atmosphere is maintained. Maintaining the high level of ferrous oxalate in the leach liquor using an inert gas was found to enhance the reaction kinetics [3]. It is believed that during this process, removal of phosphorus from the iron compound and subsequent dissolution of the phosphorus oxide formed were effected. 
It has been reported [4] that the optimum $\mathrm{pH}$ for dissolving iron oxide is $\mathrm{pH} 2.5-3.0$. The solution $\mathrm{pH}$ governs the distribution of various oxalate ions in the leach system. Below $\mathrm{pH} 1.5$, oxalic acid exists mainly as $\mathrm{H}_{2} \mathrm{C}_{2} \mathrm{O}_{4}$, whereas $\mathrm{HC}_{2} \mathrm{O}_{4}$ is the most predominant species at $\mathrm{pH} 2.5-$ 3.0.

Final $\mathrm{pH}$ of leaching solution has been found to depend on the leaching time, initial $\mathrm{pH}$ for the leaching solution and the leaching temperature $[5,6]$.

Models for computational analysis of the concentration of dissolved haematite and heat absorbed by oxalic acid solution during leaching of iron oxide ore have been derived [7]. These models are:

$$
\begin{gathered}
\% \mathrm{Fe}_{2} \mathrm{O}_{3}=\mathrm{K}(\gamma / \mu) \\
\mathrm{Q}=\mathrm{K}_{\mathrm{C}} \mu
\end{gathered}
$$

Where:

$\% \mathrm{Fe}_{2} \mathrm{O}_{3}=$ Concentration of dissolved haematite in oxalic acid solution.

$\gamma=$ Final $\mathrm{pH}$ of the leaching solution at time $\mathrm{t}$ at which $\% \mathrm{Fe}_{2} \mathrm{O}_{3}$ was obtained.

$\mu=$ Weight of iron oxide added into the oxalic acid leaching solution (g)

$\mathrm{K}=$ Constant of proportionality associated with haematite dissolution

$\mathrm{K}_{\mathrm{C}}=$ Constant of proportionality associated with heat absorption

$\mathrm{Q}=$ Quantity of heat absorbed by oxalic acid solution during the leaching process $(\mathrm{J})$

Nwoye [7] found that optimization of the weight input of iron oxide ore could be achieved using the model; $\left(\% \mathrm{Fe}_{2} \mathrm{O}_{3}=\mathrm{K}(\gamma / \mu)\right)$ by comparing the concentrations of dissolved haematite at different weights input of the iron oxide ore, with the view to identifying the optimum weight input of iron oxide ore that gives the maximum dissolution of $\mathrm{Fe}_{2} \mathrm{O}_{3}$. The model also indicates that the concentration of haematite dissolved during the leaching process is directly proportional to the final $\mathrm{pH}$ of the leaching solution and inversely proportional to the weight input of the iron oxide ore.

It was also found [7] that values of $Q$ obtained from both the experiment and model $\left(Q=K_{C} \mu\right)$ agree to the fact that leaching of iron oxide ore using oxalic acid solution is an endothermic process, hence the absorbed positive heat energy by the leaching solution. The quantity of heat energy absorbed by the oxalic acid solution during the leaching process (as calculated from the model; $\mathrm{Q}=\mathrm{K}_{\mathrm{C}} \mu$ ) was found to be directly proportional to the weight input of the iron oxide ore. These results were obtained at initial $\mathrm{pH} 6.9$, average grain size of $150 \mu \mathrm{m}$ and leaching temperature of $30^{\circ} \mathrm{C}$. The constants of proportionality $\mathrm{K}$ and $\mathrm{K}_{\mathrm{C}}$ associated with the respective derived models were evaluated to be 0.0683 and 66.88 respectively.

Several works [8-13] have been carried out to remove phosphorus from steel during steel making. All these works carried out, pointed out low treatment temperature and high oxygen activity as the only essential and unavoidable process conditions which can enhance the rate of 
dephosphorization. High activity of $\mathrm{CaO}$; a product of decomposition of $\mathrm{CaCO}_{3}$ and a slag forming material is required for enhancement of the dephosphorization process with the phosphorus forming part of the slag. This process involves pyrometallurgy and is capital intensive.

It has been reported [14] that the removal of phosphorus from iron can be achieved only by oxidation during steel making, under a basic slag.

Nwoye [15] derived a model for predicting the time for dissolution of pre-quantified concentration of phosphorus during leaching of iron oxide ore in oxalic acid solution as:

$$
\tau=\left(\frac{\log \left(\frac{\mathrm{P}^{1 / 4}}{1.8}\right)}{\log \mathrm{T}}\right)
$$

Where

$\mathrm{T}=$ Leaching temperature $\left({ }^{0} \mathrm{C}\right)$ in the experiment [16], taken as specified leaching temperature $\left({ }^{0} \mathrm{C}\right)$ aiding the expected dissolution of phosphorus .

$\mathrm{N}=1.8$ (Dissolution coefficient of phosphorus in oxalic acid solution during leaching of iron oxide ore) determined in the experiment [16].

$\mathrm{P}=$ Concentration of dissolved phosphorus $(\mathrm{mg} / \mathrm{Kg})$ in the experiment [16], taken as pre-quantified concentration of phosphorus expected to dissolve after a leaching time $t$ in the model.

$\tau=$ Leaching time (sec.) in the experiment [16], taken as time for dissolution of the prequantified concentration of phosphorus (hrs) in the model.

The model was found to depend on a range of specified leaching temperatures $\left(45-70^{\circ} \mathrm{C}\right)$ for its validity. It was found [16] that the time for dissolution of any given concentration of phosphorus decreases with increase in the leaching temperature (up to $70^{\circ} \mathrm{C}$ ), at initial $\mathrm{pH} 5.5$ and average grain size of $150 \mu \mathrm{m}$.

Nwoye et al. [17] also formulated a model for predicting the concentration of phosphorus removed during leaching of iron oxide ore in oxalic acid solution. It was found to predict the removed phosphorus concentration, with utmost dependence on the final $\mathrm{pH}$ of the leaching solution and weight input of the iron oxide ore. The model indicates that the concentration of phosphorus removed is inversely proportional to the product of the weight input of the iron oxide ore and the final $\mathrm{pH}$ of the leaching solution. Process conditions considered during the formulation of the model [17] include: leaching temperature of $25^{\circ} \mathrm{C}$, initial solution $\mathrm{pH} 5.5$ and average ore grain size; $150 \mu \mathrm{m})$.

Biological processes for phosphorus removal have also been evaluated based on the use of several types of fungi, some being oxalic acid producing. Anyakwo and Obot [18] recently presented their results of a study on the use of Aspergillus niger and their cultural filtrates for 
removing phosphorus from Agbaja (Nigeria) iron oxide ore. The results of this work [18] show that phosphorus removal efficiencies at the end of the 49 days of the leaching process are 81,63 and $68 \%$ for 5, 100 and 250 mesh grain sizes respectively.

An attempt has been made in the past [19] to leach Itakpe iron oxide ore using oxalic acid solution in order to determine the maximum concentration of phosphorus that is removable. Results of chemical analysis of the ore indicate that the percentage of phosphorus in the ore is about $1.18 \%$, which from all indication is quite high and likely to affect adversely the mechanical properties of the steel involved; hence the need for dephosphorization. It was reported [19] that phosphorus can be removed from iron oxide ore through a process associated with hydrometallurgy. Phosphorus was removed at a temperature of $25^{\circ} \mathrm{C}$ and initial solution $\mathrm{pH}$ 2.5, leading to the dissolution of the phosphorus oxide formed. This involved using acid leaching process to remove phosphorus from the iron oxide ore in readiness for steel making process.

The aim of this work is to derive a model for evaluation of the concentration of phosphorus removed relative to the final $\mathrm{pH}$ (only) of the solution during leaching of Itakpe (Nigerian) iron oxide ore using oxalic acid solution. This derivation is embarked on in furtherance of the previous work [19].

\section{MODEL}

The solid phase (ore) is assumed to be stationary, contains the un-leached iron remaining in the ore. Hydrogen ions from the oxalic acid attack the ore within the liquid phase in the presence of oxygen.

\subsection{Model Formulation}

Experimental data obtained from research work [19] carried out at SynchroWell Research Laboratory, Enugu were used for this work.

Results of the experiment as presented in report [19] and used for the model formulation are as shown in Table 1.

Computational analysis of the experimental data [19] shown in Table 1, resulted to Table 2 which indicate that;

$$
\begin{aligned}
& \ln \mathrm{P}=\mathrm{N} / \alpha \text { (approximately) } \\
& \mathrm{P}=\mathrm{e}^{\mathrm{N} / \alpha}
\end{aligned}
$$

Introducing the value of $\mathrm{N}$ into equation (5)

$$
\mathrm{P}=\mathrm{e}^{(12.25 / \alpha)}
$$

where

$\mathrm{P}=$ Concentration of phosphorus removed during the leaching process $(\mathrm{mg} / \mathrm{Kg})$ 
$\mathrm{N}=12.25$; ( $\mathrm{pH}$ coefficient for phosphorus dissolution in oxalic acid solution.) determined in the experiment [19].

$\alpha=$ Final $\mathrm{pH}$ of the leaching solution at the time $\mathrm{t}$ when the concentration of dissolved phosphorus is evaluated.

Equation (6) is the derived model.

Table1. Variation of final $\mathrm{pH}$ of leaching solution with concentration of phosphorus removed [19].

\begin{tabular}{|l|l|l|}
\hline $\mathrm{M}(\mathrm{g})$ & $(\alpha)$ & $\mathrm{P}(\mathrm{mg} / \mathrm{Kg})$ \\
\hline 2 & 2.98 & 62.70 \\
3.5 & 3.06 & 60.81 \\
4 & 3.19 & 59.60 \\
6 & 3.20 & 45.60 \\
8 & 3.29 & 44.20 \\
9 & 3.38 & 37.40 \\
10 & 3.45 & 31.60 \\
\hline
\end{tabular}

Where $\mathrm{M}=$ Mass of iron oxide ore used for the leaching process $(\mathrm{g})$.

Table 2. Variation of $\ln \mathrm{P}$ with $\mathrm{N} / \alpha$.

\begin{tabular}{|l|l|l|}
\hline $\mathrm{M}(\mathrm{g})$ & $\ln \mathrm{N} / \alpha$ \\
\hline 2 & 4.1352 & 4.1107 \\
4 & 4.1078 & 4.0033 \\
6 & 4.0877 & 3.8401 \\
8 & 3.8200 & 3.8281 \\
10 & 3.7887 & 3.7234 \\
14 & 3.6217 & 3.6567 \\
16 & 3.4532 & 3.5507 \\
\hline
\end{tabular}

\section{BOUNDARY AND INITIAL CONDITION}

Consider iron oxide ore in cylindrical flask $30 \mathrm{~cm}$ high containing leaching solution of oxalic acid. The leaching solution is stationary i.e (non-flowing). The flask is assumed to be initially free of attached bacteria. Initially, atmospheric levels of oxygen are assumed. Varying weights $(2-10 \mathrm{~g})$ of iron oxide ore were used as outlined in Table 1. The initial $\mathrm{pH}$ of leaching solution; 2.5 and leaching time of $3 \mathrm{hrs}$ were used for all samples. A constant leaching temperature of 
$25^{\circ} \mathrm{C}$ was used. Ore grain sizes at $150 \mu \mathrm{m}$ (average) and oxalic acid concentration at $0.1 \mathrm{~mol} / \mathrm{litre}$ were used. These and other process conditions are as stated in the experimental technique [19].

The boundary conditions are: atmospheric levels of oxygen (since the cylinder was open at the top) at the top and bottom of the ore particles in the liquid and gas phases respectively. At the bottom of the particles, a zero gradient for the liquid scalar are assumed and also for the gas phase at the top of the particles. The leaching solution is stationary. The sides of the particles are taken to be symmetries.

\section{MODEL VALIDATION}

The formulated model was validated by direct analysis and comparism of $\mathrm{P}$ values from model data and those from the experimental data for equality or near equality.

Analysis and comparism between these data reveal deviations of model-predicted $\mathrm{P}$ values from those of the experiment. This is believed to be due to the fact that the surface properties of the ore and the physiochemical interactions between the ore and leaching solution which were found to play vital roles during the leaching process [19] were not considered during the model formulation. This necessitated the introduction of correction factor, to bring the model-predicted $\mathrm{P}$ values to those of the experiment (See Table 3).

Deviation (Dv) (\%) of model- predicted $\mathrm{P}$ values from experimental $\mathrm{P}$ values is given by

$$
\mathrm{Dv}=\frac{\mathrm{Dp}-\mathrm{DE}}{\mathrm{DE}} \times 100
$$

Where $\quad \mathrm{Dp}=$ Model-predicted $\mathrm{P}$ values

$\mathrm{DE}=$ Experimental $\mathrm{P}$ values

Correction factor $(\mathrm{Cf})$ is the negative of the deviation i.e

$$
\mathrm{Cf}=-\mathrm{Dv}
$$

Therefore

$$
C f=-100\left(\frac{D p-D E}{D E}\right)
$$

Introduction of the corresponding values of $\mathrm{Cf}$ from equation (9) into the model gives exactly the corresponding experimental $\mathrm{P}$ values [19].

\section{RESULTS AND DISCUSSION}

The derived model is equation (6). A comparison of the values of $\mathrm{P}$ from the experimental data and those from the model show very insignificant positive and negative deviations, hence depicting the reliability and validity of the model. This is shown in Table 3 . The positive and negative deviation of the model-predicted $\mathrm{P}$ values from those of the experiment is less than $22 \%$ which is quite within the acceptable deviation limit of experimental results. The validity of the 
model is believed to be rooted on equation (4) where both sides of the equation are approximately equal to 4 . Table 2 also agrees with equation (4) following the values of $\ln \mathrm{P}$ and N/ $\alpha$ evaluated from Table1.

Table 3. Comparison between concentrations of phosphorus removed as predicted by model and as obtained from experiment [19].

\begin{tabular}{|l|l|l|l|}
\hline $\mathrm{P}_{\exp }(\mathrm{mg} / \mathrm{Kg})$ & $\mathrm{P}_{\mathrm{M}}(\mathrm{mg} / \mathrm{Kg})$ & $\mathrm{Dv}(\%)$ & $\mathrm{Cf}(\%)$ \\
\hline 62.70 & 61.00 & -2.71 & +2.71 \\
60.81 & 54.78 & -9.92 & +9.92 \\
59.60 & 46.53 & -21.93 & +21.93 \\
45.60 & 45.98 & +0.83 & -0.83 \\
44.20 & 41.41 & -6.31 & +6.31 \\
37.40 & 37.50 & +0.27 & -0.27 \\
31.60 & 34.84 & +10.25 & -10.25 \\
\hline
\end{tabular}

\section{CONCLUSION}

The model was used to evaluate the concentration of phosphorus removed (relative to the solution $\mathrm{pH}$ ) during leaching of Itakpe iron oxide ore. The validity of the model is believed to be rooted on the relationship $\ln \mathrm{P}=\mathrm{N} / \alpha$ where both sides of the expression are approximately equal to 4 .

Further works should incorporate more process parameters into the model with the aim of reducing the deviation of the model-predicted $\mathrm{P}$ values from those of the experiment.

\section{ACKNOWLEDGEMENT}

The author thanks Dr. Ekeme Udoh, a modelling expert at Linkwell Modelling Centre Calabar for his technical inputs. The management of SynchroWell Nig. Ltd. Enugu is also appreciated for permitting and providing the experimental data used in this work.

\section{REFERENCES}

[1] Taxiarchour, M., Panias, D., Doumi, I., Paspaliaris, I., Kontopoulos, A. (1997a) Removal of Iron from Silica Sand by Leaching with Oxalic Acid, Hydrometallurgy, 46, 215-227.

[2] Taxiarchou, M., Parnias, D., Douni, I., Paspaliaris, I., Kontopoulous, A. (1997b) Dissolution of Haematite in Acidic Oxalate Solutions. Hydrometallurgy, 44, 287-299.

[3] Lee, S. O., Tran, T., Park Y.Y., Kim S.J., Kim, M. J. (2006) Study on the Kinetics of Iron Leaching by Oxalic Acid. Int. J. Miner Process, 80, 144-152.

[4] Panias, D.,Taxiarchou, M., Paspaliaris, I., Kontopoulos, A. (1996) Mechanism of Dissolution of Iron Oxides in Aqueous Oxalic Acid. Hydrometallurgy 42, 257-265. 
[5] Pinches, A. (1975) Bacterial Leaching of an Arsenic Bearing Sulphide Concentrate. The Institute of Mining and Metallurgy, England, 34.

[6] Nwoye, C. I. (2008) Ph.D Thesis, Metallurgical and Materials Engineering Department, Federal University of Technology, Owerri, 178.

[7] Nwoye, C. I. (2008) Model for Computational Analysis of Dissolved Haematite and Heat Absorbed by Oxalic Acid Solution during Leaching of Iron Oxide Ore, J. Eng.\& App. Sc., 4, 22-25.

[8] Turkdogan, E.T., Pearson, J. (1953) J. Iron and Steel Inst., 221, pp. 393-401.

[9] Decker, A., Sevrin, R., Scimar, R. (1962) Open Hearth Proceedings, 45, pp. 421- 456.

[10] Duke, D. A., Ramstad, H. F., Meyer, H. W. (1962) Open Hearth Proceedings, vol 45, pp.8198.

[11] Kootz,T., Neuhaus, H. (1961) Stahl u. Eisen, 81, pp. 1810-1815.

[12] Kootz, K., Behrens,K., Maas, H., Baumgarten,. P. (1965) Stahl u. Eisen, 85, pp 857-865.

[13] Edneral, F. P. (1979) Electrometallurgy of Steel and Ferro-alloys, MIR Publisher, $5^{\text {th }}$ edition Moscow. pp 30-239.

[14] Zea,Y. K. (1945) J. Iron and Steel Inst., 151, pp. 459-504.

[15] Nwoye, C. I. (2008) Model for predicting the Time of Dissolution of Pre-quantified Concentration of Phosphorus during Leaching of Iron Oxide Ore in Oxalic Acid, IJONAS, 4(3):168-174.

[16] Nwoye, C. I. (2006) SynchroWell Research Work Report, DFM Unit, No 2561178, 66-83. [13]

[17] Nwoye, C. I., Agu, P. C., Mark, U., Ikele, U. S., Mbuka, I. E., and Anyakwo, C. N. (2008) Model for Predicting Phosphorus Removal in Relation to Weight of Iron Oxide Ore and $\mathrm{pH}$ during Leaching with Oxalic Acid Inter. J. Nat. Appl. Sc., 4(3): 106-112.

[18] Anyakwo, C. N., and Obot, O.W. (2008) Phosphorus Removal from Nigeria`s Agbaja Iron Ore by Aspergillus niger, IREJEST 5(1), 54-58.

[19] Nwoye, C. I. (2003) SynchroWell Research Work Report, DFM Unit, No 2031196, 26-60. 